\title{
Reassignment ${ }^{1}$ of Mycs gene to mouse chromosome $\mathrm{XA1.2-2}$ by radiation hybrid mapping and fluorescence in situ hybridization
}

\author{
Z.H. Shan and N.C. Popescu \\ Laboratory of Experimental Carcinogenesis, Center for Cancer Research, National Cancer Institute, Bethesda MD (USA) \\ 1 This report is discordant with a previous assignment of this gene to chromosome 19B using FISH by Sugiyama et al. \\ (1999).
}

\section{Rationale and significance}

The mouse $M y c s$ gene is a member of the intronless $M y c$ gene family. Both human and rat Mycs genes have been mapped to chromosome X (Moton et al., 1989; Serikawa et al., 1992), while the mouse Mycs was initially localized by fluorescence in situ hybridization (FISH) to chromosome 19B (Sugiyama et al., 1999). The apoptosis-inducing activity of intronless $M y c$ genes is evolutionarily conserved in mammalian cells but is somewhat distinct from $c-m y c$ although both require activation of caspase-3 like proteases (Asai et al., 1994; Kagaya et al., 1997, Sugiyama et al., 1999). As a part of our attempt to identify the genes amplified from double minute chromosomes originating from mouse chromosome 19 identified in a hepatocellular carcinoma developed in $M y c$ transgenic mice (Zimonjic et al., 2001), we found by FISH and radiation hybrid (RH) mapping that the mouse Mycs gene is located on the X chromosome. This localization confirms the recent correct assignment of Mycs gene on the X chromosome by RH only (Yamasaki et al., 2001) and places the Mycs gene locus at region XA1.2-2 (Fig. 1). Furthermore, this mapping provides evidence that Mycs genes are conserved in vertebrates, consistent with their similar biological function.

\footnotetext{
Received 14 March 2002; manuscript accepted 5 April 2002.

Corresponding author: Dr. Nicholas C. Popescu

Laboratory of Experimental Carcinogenesis

Center for Cancer Research, National Cancer Institute

Building 37, Room 3C05, 37 Convent Drive, MSC4255

Bethesda, MD 20892-4255 (USA); telephone: (301) 496-5688 ext 240

fax: (301) 496-0734; email: nicholas_popescu@nih.gov
}

\section{Materials and methods}

\section{Fluorescence in situ hybridization (FISH)}

Four specific primers were designed from mouse Mycs sequence, Mycs-1 from 3' UTR (for: 5'-GTGGTGGGAGAAATGCTTTTCAGCTG-3'; rev: 5'-AGCTCAGTGGCATATCTAAGGAAGGCAAG-3') and Mycs-2 from 5' UTR (for: 5'-TCCACATGCTCTGAGTTTGTTTCTTCCCC-3'; rev: 5'GTCTCCACCTGACAACGAAACACCT- $3^{\prime}$ ). The primers were used to screen a mouse ES-129Sv/J BAC library (Genome Systems). A positive clone, $70 \mathrm{C} 10$, was identified and used for subsequent analyses based on the clone verification by PCR and sequence identity of the PCR product to Mycs sequence. BAC 70C10 DNA was labeled with digoxigenin-11-dUTP (Roche Molecular Biochemicals) by standard nick translation. Mouse X chromosome painting probe labeled with biotin-14-dCTP (Clontech) was co-hybridized with BAC $70 \mathrm{C} 10$ probe. FISH protocols were followed to map the probes to mouse metaphase chromosomes (Shan et al., 2000). Digital image acquisition was performed by using IPLab system (Scanalystics, Inc.) and image analysis was carried out as previously described (Shan et al., 2000).

\author{
Probe name: $70 \mathrm{C} 10$ \\ Probe type: mouse genomic DNA \\ Vector: pBeloBAC \\ Insert size: $75-100 \mathrm{~kb}$ \\ Gene symbol: Mycs \\ Gene name: myc-like oncogene, s-myc protein \\ Proof of authenticity: PCR and partial DNA sequencing \\ Gene reference: GenBank accession number AB016289
}

\section{Radiation Hybrid (RH) mapping}

A T31 Mouse Radiation Hybrid Panel (Research Genetics) was used for physical mapping. A 347-bp fragment of the 3' UTR region of Mycs was amplified by PCR using the primers Mycs- 1 for/rev. PCR cycling conditions were $40 \mathrm{~s}$ at $94^{\circ} \mathrm{C}, 30 \mathrm{~s}$ at $60^{\circ} \mathrm{C}$, and $40 \mathrm{~s}$ at $72^{\circ} \mathrm{C}$ for 30 cycles; the first denaturation was done for $3 \mathrm{~min}$ at $94^{\circ} \mathrm{C}$ and the final extension for $3 \mathrm{~min}$ at $72^{\circ} \mathrm{C}$. The products were separated by electrophoresis on $2.5 \%$ agarose gel and visualized with ethidium bromide staining. The results were scored by the mouse band positive (1), negative (0). A score for each of the 100 cell lines in the RH panel $(0000101000001100000000110110100000100010$ 0100000000000011100000000001001000000000000100001100011 00001) was submitted to The Jackson Laboratory RH mapping server (http://www.jax.org/resources/documents/cmdata/rhmap/rhsubmit.html, Rowe et al., 2000) for data analysis and chromosome location.

\footnotetext{
KARGER Fax +41613061234 E-mail karger@karger.ch www. karger.com

(C) 2002 S. Karger AG, Basel 0301-0171/02/0972-0152\$18.50/0
}

Accessible online at:

www.karger.com/journals/cgr 
Fig. 1. Chromosomal mapping of the mouse Mycs gene to region XA1.2-2 by FISH with chromosome X painting probe and BAC $70 \mathrm{C} 10$ probe.

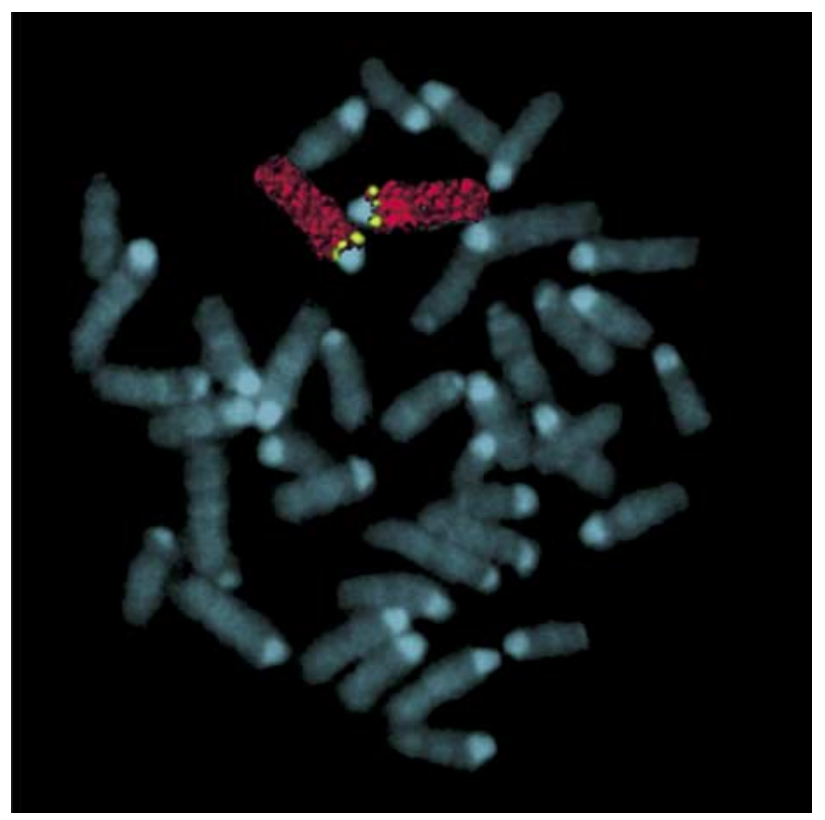

\section{Results}

\section{FISH mapping data}

Most precise assignment: XA1.2-2

Number of cells examined: 60

Number of cells with specific signal: 55

Location of background signals (site with $>2$ signals): none observed.

\section{RH mapping data:}

The Mycs gene was mapped to the interval between DXMit101 $18.1 \mathrm{cR}$ proximal and DXMit203 $33.3 \mathrm{cR}$ distal of the $\mathrm{X}$ chromosome map. The RH mapping data show a LOD score of 13.4 to DXMit101 at the proximal end of the X map, and have LOD scores for over 6 to 20 data sets in this region that represent 18 loci (six anchor MIT markers and twelve EST markers, including AF082348, an EST for Bmp15), and there are no suggestions of any alternative map position.

\section{References}

Asai A, Miyagi Y, Sugiyama A, Nagashima Y, Kanemitsu H, Obinata M, Mishima K, Kuchino Y: The s-Myc protein having the ability to induce apoptosis is selectively expressed in rat embryo chondrocytes. Oncogene 9:2345-2352 (1994).

Kagaya S, Kitanaka C, Noguchi K, Mochizuki T, Sugiyama A, Asai A, Yasuhara N, Eguchi Y, Tsujimoto Y, Kuchino Y: A functional role for death proteases in sMyc- and c-Myc-mediated apoptosis. Mol cell Biol 17:6736-6745 (1997).

Morton CC, Nussenzweig MC, Sousa R, Sorenson GD, Pettengill OS, Shows TB: Mapping and characterization of an X-linked processed gene related to MYCL1. Genomics 4:367-375 (1989).

Rowe LB, Barter ME, Eppig JT: Cross-referencing radiation hybrid data to the recombination map: lessons from mouse Chromosome 18. Genomics 69:27-36 (2000).

Serikawa T, Kuramoto T, Hilbert P, Mori M, Yamada J, Dubay CJ, Lindpainter K, Ganten D, Guenet JL, Lathrop GM, Beckmann JS: Rat gene mapping using PCR-analyzed microsatellites. Genetics 131:701-721 (1992).

Shan Z, Zabel B, Trautmann U, Hillig U, Ottolenghi C, Wan Y, Haaf T: FISH mapping of the sex-reversal region on human chromosome $9 \mathrm{p}$ in two $\mathrm{XY}$ females and in primates. Eur J hum Genet 8:167-173 (2000).

Sugiyama A, Noguchi K, Kitanaka C, Katou N, Tashiro F, Ono T, Yoshida MC, Kuchino Y: Molecular cloning and chromosomal mapping of mouse intronless $m y c$ gene acting as a potent apoptosis inducer. Gene 226:273-283 (1999).

Yamasaki Y, Helou K, Watanabe TK, Sjoling A, Suzuki M, Okuno S, Ono T, Takagi T, Nakamura Y, Stahl F, Tanigami A: Mouse chromosome 19 and distal rat chromosome 1: a chromosome segment conserved in evolution. Hereditas 134:23-34 (2001).

Zimonjic DB, Zhang H, Shan Z, Factor V, Trent J, Thorgeirsson SS, Popescu NC: DNA amplification associated with double minutes originating from chromosome 19 in mouse hepatocellular carcinoma. Cytogenet Cell Genet 93:114-116 (2001). 